\title{
EDITORIAL
}

\section{ON ANTI-CATHOLICISM, CATHOLIC COLLEGE PRESIDENTS, AND ADS FOR NONORDAINED CATHOLIC LAYPERSONS}

There is growing concern these days about anti-Catholicism. This does not necessarily mean that anti-Catholicism is increasing. Rather, what seems to be happening is that there is growing awareness that the long-standing prejudice against Catholics has not been as totally overcome as many had thought. In particular, Catholics of southern and eastern European background, despite compelling evidence of their energy, diligence, educational and economic achievement, do not score as they should on the occupational prestige index, and the hypothesis that best matches the data is that, subtly or overtly, positive exclusionary practices are at work. Prejudice. In addition, many are convinced that there is a more general prejudice against Catholics in portions of the upper reaches of academe, in some foundations and corporations, and in the frequently tasteless treatment Catholicism receives in some films and television shows.

What should be done about this?

First, one should not make too little of this. Prejudice and shabby treatment of any group should not be tolerated. Gaps of consciousness in the public mind about these kinds of practices and the feelings of annoyance, anger, and frustration, and indeed, the injustice involved, need to be addressed.

But the rightful attention to residual anti-Catholic prejudice should not be built into a focal point for the identity of Catholics. The challenge of articulating and achieving a positive identity for Catholics in the United States is now the major task, and some progress is being made on that task. Making residual anti-Catholicism the focal point for Catholic identity will be a step backwards from that important challenge.

Thus we have maintained that one should not make either too little or too much of anti-Catholic prejudice.

Second, one should be consistent in any concern with prejudice. Prejudice within Catholicism against any class or group should be attended to with at least as much vigor as is prejudice from outside the Catholic community. In this regard, let us reflect on a couple of issues which may be well within the realm of experience of readers of Horizons and members of the College Theology Society.

Issue \#1: Should we not call into question practices or policies in much of Catholic higher education which limit the selection of the Presidents of these institutions to members of the founding religious order or society? Let us consider some of the more outstanding of these 
institutions. Should it be policy in practice that no one but a Jesuit may serve as president of one of the twenty-eight colleges historically founded by Jesuits? Should the selection of the next President of the University of Notre Dame be limited only to members of the Congregation of the Sacred Cross? These are merely specific examples which could be multiplied.

"Ah," you say, "this fellow has no sense of symbolism!" But I would counter that nervous preoccupation with the symbolism, identity, and power associated with narrowly confining these college or university offices of president, might profitably be placed alongside some of the uneasy and prejudiced questioning that preceded the election of John Kennedy in 1960.

Consider the following passage from The Commonweal and American Catholicism:

In April, 1958, John Cogley wrote in his Commonweal column that the way the Kennedy boom was booming, the questions which had already been revived about whether a Catholic could ever reach the White House were going to be heard more and more frequently. Cogley said that what he found hard to take was some of the talk in which what was a matter of prejudice was so often put forth as "a grave intellectual quandary." He didn't doubt the sincerity of those who professed to be tortured by the question, but commented: "I do believe, though, they are working out a personal problem and have reached the stage where they feel a need to rationalize a position that is anything but rational. Anyone who has ever had to overcome a prejudice of his own, and most of us have, knows what they are going through." If a Catholic couldn't be trusted with the presidential office because of his religious commitments, could he be any more trustworthy as a senator or as a Supreme Court justice? Cogley said he suspected that the real reason why the presidency seemed to make such a difference was that it was an office that was at least partly symbolic. "In his person he represents the American people before the world. This means for many that he should belong to the dominant ethnic and religious group."

The changing symbolism involved in 1960 prompted a panicked Reverend Norman Vincent Peale to state: "Our American culture is at stake. I don't say it won't survive [Kennedy's election], but it won't be what it was." Was this attitude toward Kennedy, however, really much different from what one might hear now from some who might contemplate the emergence of a Catholic layperson to an important Catholic college presidency such as those I've mentioned above? How many

'Rodger Van Allen, The Commonweal and American Catholicism (Philadelphia: Fortress Press, 1974), pp. 131-132.

'Upon hearing Peale's statement, Kennedy remarked, "I would like to think he was complimenting me, but I'm not sure he was." 
Catholic Norman Vincent Peales would be saying similar things in a scenario involving the presidency of many Catholic colleges?

Issue \#2: Let us mention one other problematic situation regarding de facto prejudicial practices. Not long ago, TOIL, the teaching opportunities information listing published by the Council on the Study of Religion contained an ad for a moral theologian. The ad mentioned the various qualities desired, pointed out that the institution was an affirmative action-equal opportunity employer, and concluded: "Position envisions a Roman Catholic priest or unordained layperson." This curious phrase "unordained layperson" clearly conveys the message that no former Catholic clerics will be considered by this "equal opportunity employer." The point of this example is not to attack the institution involved, which has at least been clear in its prejudicially exclusionary policy, but to illustrate a continuing problem in many places. Less admirable than this particular institution are those who would smirk at the curious phraseology of the ad but covertly follow the same policy.

So let us by all means not neglect attending to those remaining pockets of anti-Catholic prejudice and those gaps of consciousness that are equivalently the same, but let us also be sensitized anew to possibly prejudicial gaps of consciousness within Catholicism such as those we have mentioned. The above examples are shared in the spirit of reflecting on Chapter III of the 1971 Synod document, "Justice in the World," which holds that everyone who ventures to speak to people about justice must be careful to be just. Similarly those who venture to speak of prejudice must be careful to avoid prejudice. As Catholics and others enter into matters dealing with justice and prejudice may it be done with a self-scrutiny that will be enriching to all.

-RODGER VAN ALLEN

\section{WEAR COMFORTABLE CLOTHES, BRING BROWN PAPER BAG}

Mysticism has come to suburbia. The event might well have passed without notice, had the New York Times not begun a Sunday supplement covering Westchester.

“Modern Mysticism," panel discussion today at 4 P.M. to 6. $\$ 7.50$, students $\$ 5$, with dinner and discussion afterward $\$ 15$. Workshop, Wednesday at 10 A.M. to 2 P.M. \$10. Wear comfortable clothes, bring brown paper bag that will fit over your head. Center for Human Potential, Fawn Ridge.

"Total Environments: Mystical Adornments for the Body,"' by Alex and Lee. The Gallery, Green Glades. 